\title{
A climatological study of the trospospheric circulation over the Amazon region
}

\author{
Vernon E. Kousky ( $\left.{ }^{*}\right)$ \\ Mary T. Kagano [*]
}

\begin{abstract}
Climatological and monthly means are computed for radiosonde data at Manaus and Belém (1968-1976). Geopotencial height and wind data at upper levels show evidence of the meridional movement of a strongly divergent high pressure system associated with the area of maximum convection. At low levels, the winds, particularly at Manaus, show an annual cycle linked to the meridional displacement of the equatorial trough and its accompanying area of maximum convection (upper level high pressure system). On the average, the precipitable water $(\mathrm{Pw})$ is greater at Manaus than at Belém. However, evidence is presented indicating that this is not always the case and that considerable diurnal variation in Pw exists at each station. Mean monthly vertical motions are calculated for the area within the triangle formed with Belém. Manaus and Vilhena as the vertices. These vertical motions show a strong relationship to monthly rainfall totals within the triangle indicating that interannual and monthly rainfall variations may be due to large scale atmospheric circulation changes.
\end{abstract}

\section{INTRODUCTION}

Until the late 1960 's radiosonde data for the Amazon Basin were virtually non-existent, and little was know about the mean atmospheric circulation of the region. The first studies to incorporate radiosond edata for this region were those by Dean (1971) and Newell et al. (1972). In both studies, less than two years of data were available from the Amazon region. Marques et al. (1977) studied precipitable watei and water vapor flux for the Amazon Basin based on the radiosonde data for Manaus and Belém during 1974. Obviously, the amount of data used in the above studies is insufficient to establish climatological means.

In an attempt to establish more representative means for the wind and temperature fields Sobral (1979) analyzed upper air data for all of
South America for the period 1969-1973. Marques (1978) made a comprehensive study of the upper air circulation over the Amazon Basin, using radiosonde data for several stations in northern South America for the period 1972-1975. He concluded that the Atlantic Ocean supplies water vapor to the Amazon region throughout the year and that seasonal variations in rainfall are due to the apparent meridional displacement of the Sun. Marques noted that the layer from the surface up to $500 \mathrm{mb}$ is characterized by water vapor flux convergence over most of the Amazon Basin implying that the region acts as a water vapor sink.

Mlarques made no reference to year-to-year variations in rainfall, although large variations from the mean of $\pm 30 \%$ do occur. These variations may be due to large scale tropospheric circulation changes within mid-latitudes, such as those which have been related to rainfall variability over the semi-arid regions of Northeast Brazil (Namias, 1972; Hastenrath \& Heller. 1977; Kousky, 1979). The effects that such changes have on the tropical circulation are still not clearly understood. However, the mid-latitude circulation pattern may affect the pattern of divergence and convergence within the tropics, as suggested by Namias (1972) and Kousky (1979), which would alter the tropical circulation pattern.

In this paper we will describe certain aspects of the upper air climatology for the Amazon Basin based on radiosonde data for the period 1968-1976. Special emphasis will be given to physical explanations for observed characteristics. Clearly, the results for such a short period of time must be considered tentative.

(*) - Instituto de Pesquisas Espaciais. São José dos Campos, SP. 
DATA

The radiosonde data for the period 1968-1976 were acquired from the National Climatic Center (NCC), Asheville, North Carolina, U.S.A., and are archived on magnetic tape. In general, the data available from NCC represent only a fraction of the total number of observations made. With the assistance of the Instituto de Atividades Espacias, (IAE), which is a part of the Centro Técnico Aeroespacial, São José dos Campos, Brazil, radiosonde data were acquired for Belém $\left(1^{\circ} 23^{\prime} S, 48^{\circ} 29^{\prime} \mathrm{W}\right)$ and Manaus $\left(3^{\circ} 8 \mathrm{~S}, 60^{\circ} 1^{\prime} \mathrm{W}\right)$ for the period 1 January-31 December 1974. These data will be compared in this article to the data available trom NCC.

A!l data were subjected to consistency checks in order to filter out errors. Temperature data were considered erroneous if the lapse rate became superadiabatic. This test should be fairly reliable, since the data available were taken at 8-9 AM and 8-9 PM during times when surface superadiabatic lapse rates do not normally occur. Once detected, erroneous temperatures were replaced by interpolated values. Relative humidity was, in general, left with its original value, wind data were checked for vertical consistency, and geopotential heights were calculated using the hypsometric equation. Precipitable water was calculated using data at both significant and standard levels up to the level at which the temperature became colder than $-40.1^{\circ} \mathrm{C}$ and relative humidity data were no longer available.

\section{RESULTS (Climatological means)}

GEOPOTENTIAL HEIGHT AND SURFACE PRESSURE

The monthly climatological means for geopotential herght, calculated using the entire data record (1968-1976), are shown in Fig. 1. The curves for Manaus and Belém have certain basic similarities, such as the annual oscillation at low levels and the semiannual oscillation at high levels. The maximum geopotential height, for the upper troposphere (300-200 mb), occurs at both stations during the Southern Hemisphere Fall season (AprilMay). A secondary maximum at high levels occurs in the Spring (October at Belém and Noverber at Manaus). At low levels a single maximum is observed during the Southern Hemisphere Winter (July) and a single broad minimum is observed during the Summer months. At all levels the curves show more irregularity at Manaus than at Belém. The curves for surface pressure (Fig. 2) show characteristics similar to the curves of geopotential height at $1000 \mathrm{mb}$.

\section{WIND}

The monthly climatological mean zonal (u) and meridional ( $v$ ) wind components for Manaus and Belém are shown in Figs. 3 and 4, respectively. At high levels $(200 \mathrm{mb})$, at Manaus, the wind is from the south or southeast during the period December through April. The wind abruptly shifts to the northwest in May with the westerly component continuing until November and the northerly component continuing until September.

At low levels ( $850 \mathrm{mb}$ ) the u-component remains negative (easterly) throughout the year, while the v-component is positive (southerly) during the period May-August and negative (northerly) the rest of the year. The northerly component is strongest from January to March.

At Belém the situation is somewhat different. Near $200 \mathrm{mb}$ winds are predominantly southwesterly during the period October to March, southeasterly in April and westerly or northwesterly from May to September. At low levels, southeasterly winds prevail throughout the year reaching a distinct maximum in July and a relative minimum from February through April.

\section{RELATIVE HUMIDITY AND PRECIPITABLE WATER}

The monthly climatological means of relative humidity are shown in Fig. 5. In general, the two stations show quite similar results with the relative humidity being highest during the period January-April and lowest from June through September. The annual variability of relative humidity increases with increasing height. 

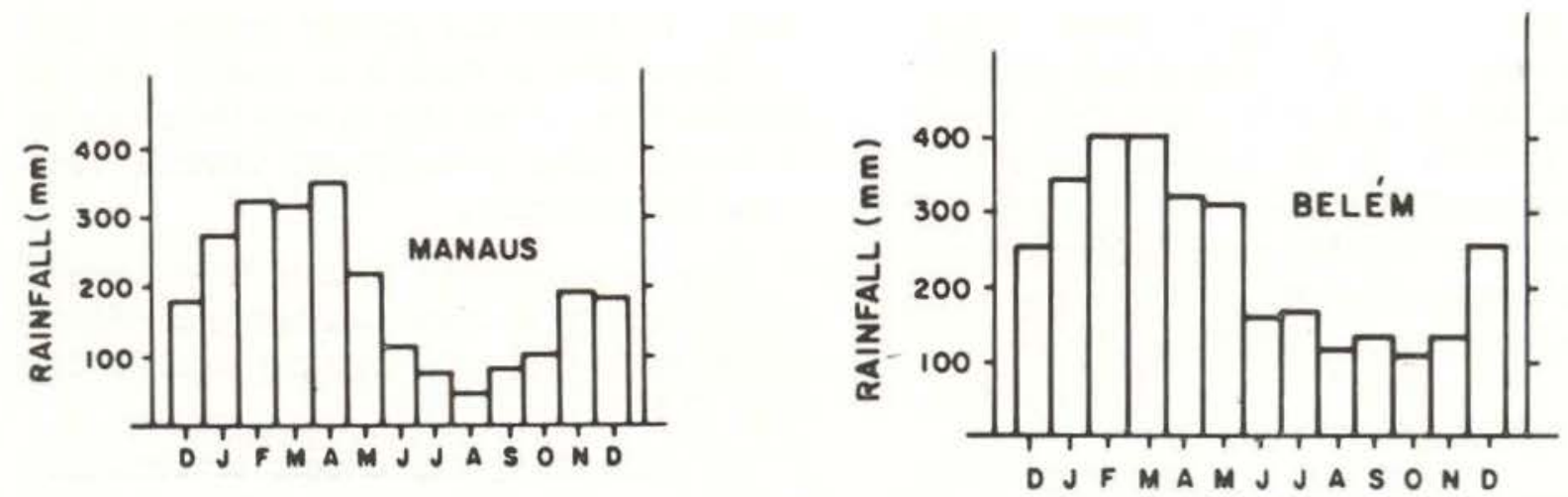

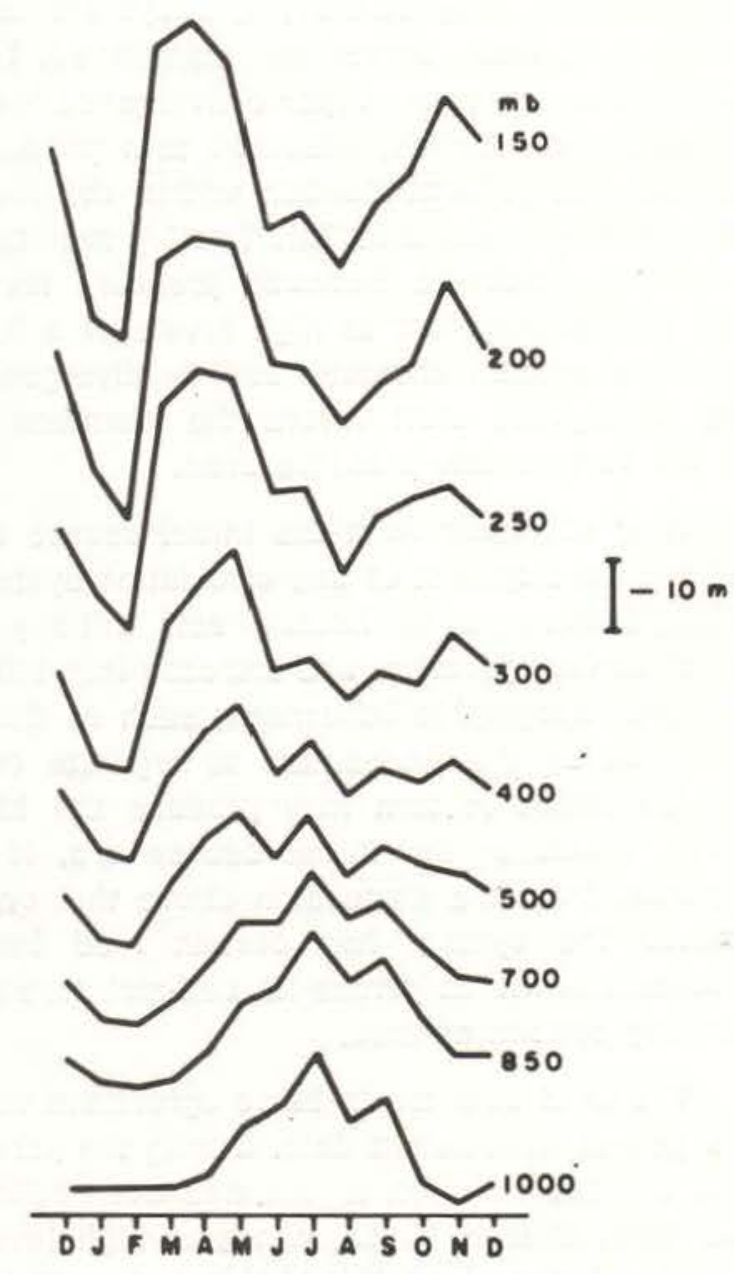

(a)

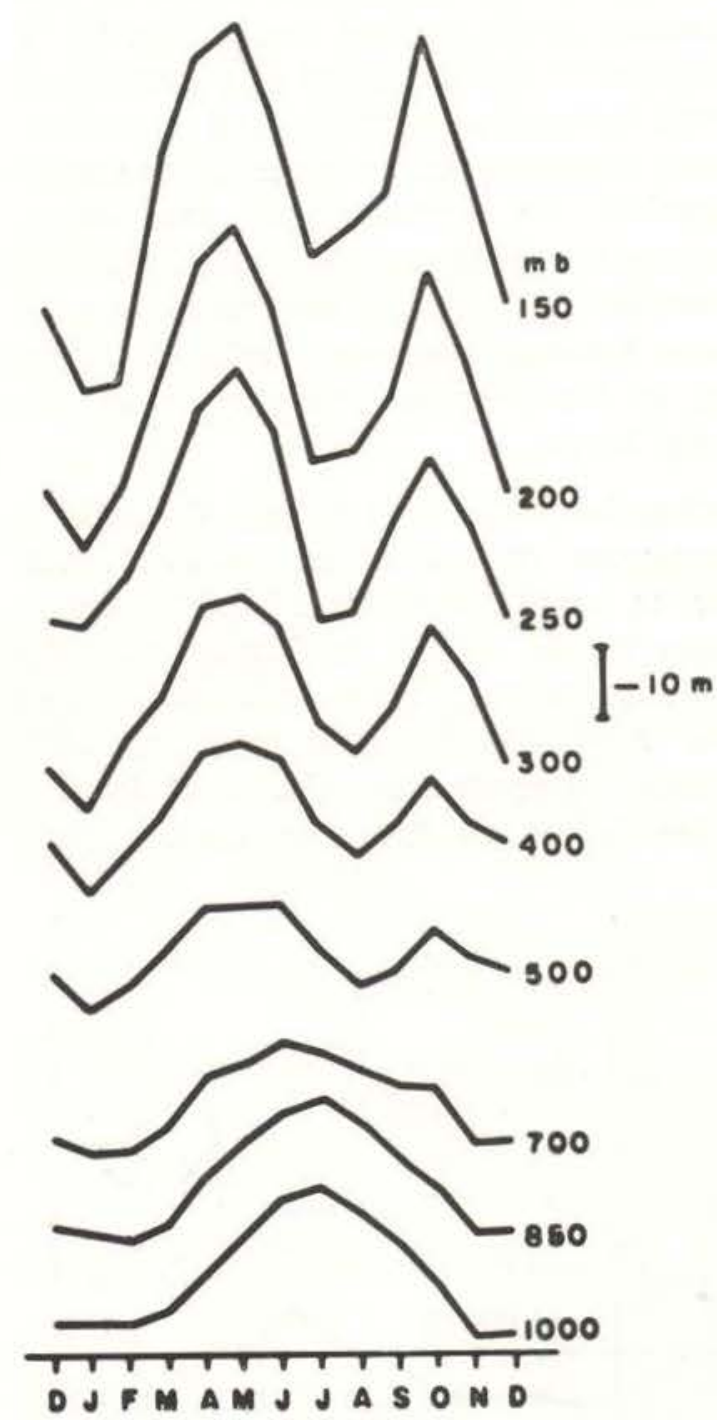

(b)

Fig. 1 - Deviations of geopotencial height (at standard pressure levels) from the climatological means and histogram of monthly mean rainfall computed for the period 1968-7976 at (a) Manaus and (b) Belém. Height scaie is indicated at right of figure. 
The monthly climatological means of precipitable water (Fig. 6) hav an annual variation similar to that of relative humidity. Fig. 6 also shows a fairly good positive correlation between precipitable water and precipitation. One also notes that the precipitable water is greater at Manaus than at Belém, a feature also noted by Marques et al. (1977) and by Marques (1978).

\section{Discussion (Climatological means)}

The semiannual oscillation noted in the geopotentian height, at high levels (Fig. 1), is probably due to the latitudinal displacement of maximum convective activity and, therefore, maximum precipitation. In areas of maximum precipitation the atmosphere, experiences heating due to the release of latent heat during condensation. This heating produces a greater thickness between pressure levels, thus producing, at high levels a maximum in geopotential height.

During the period June through September, the maximum rainfall occurs north of the equator in southern Venezuela and eastern Coiombia (Snow, 1976). In October and Noverber this activity shifts southward over western Amazonas and continues to shift southward and southeastward until in January it reaches the area of Bolivia and Mato Grosso,

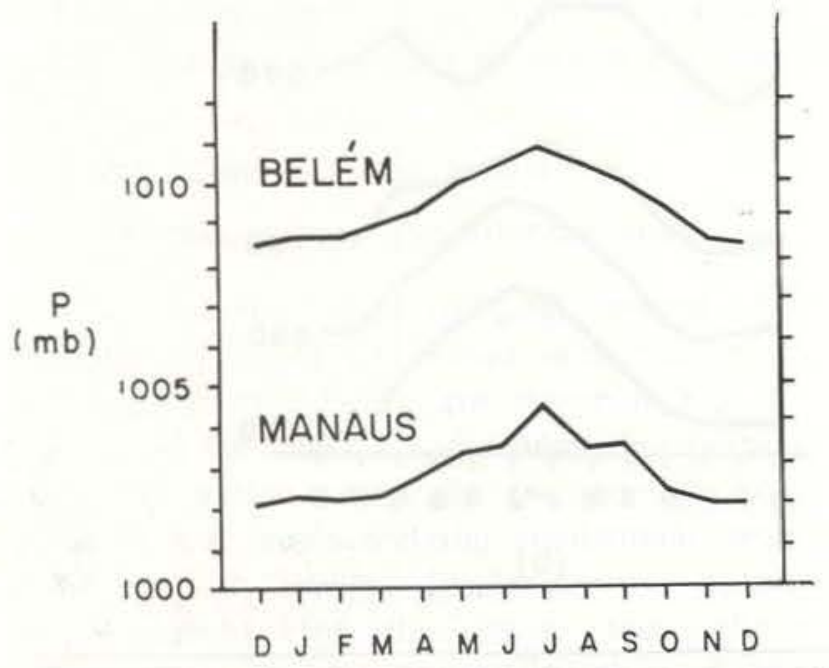

Fig. 2 - Monthly Climatological means of surface pressure for Manaus and Belém.
Brazil. In March the activity begins to shift northward until in April it is located over the Amazon River. From May to June the maximum in rainfall shifts nortwestward towards Venezuela and Colombia.

This same seasonal shift in maximmu convective activity is noted in average brightness charts made from polar orbiting satellite data (Fig. 7).

By considering the effects of continuity, divergence at high levels must be associated with rising air motion at mid-levels and convergence at low levels. This signifies that at low levels, in the region of maximum convective activity, relatively low pressure must be present. Once formed, the system as a whole is to some degree self-maintained. Low level mass and water vapor convergence leads to strong convection, which in turn produces heating due to condensation within the lower and middle troposhere. This heating results in a greater thickness between pressure levels and the development at high levels of a high pressure system characterized by divergence. The divergence aloft favors the maintenance of the surtace low pressure area.

It is not clear what the initial causes are for the development of this circulation system. Perhaps strong solar heating acts initially to lower surface pressure and increase instability. Perhaps topographic influences, such as those produced by the Andes, act to organize convection which in turn may produce the high aloft. Whatever the initial causes are, it is apparent from the discussion above that once formed the system has certain feed back mechanisms which permit its self-maintenance for long periods of time.

The wind data are in basic agreement with the geopotential height data. During the period that the $200 \mathrm{mb}$ high is situated over Bolivia and Mato Grosso, Brazi!, winds at high levels strongly diverge from this region and cross the equator (e.g. south-southeasterly winds at Manaus and southerly winds at Belém). This wind distribution is similar to that obtained by Newell at al. (1972) (see Fig. 8). The low level winds at Manaus are from the northeast thus supporting the idea of a surface low pressure 


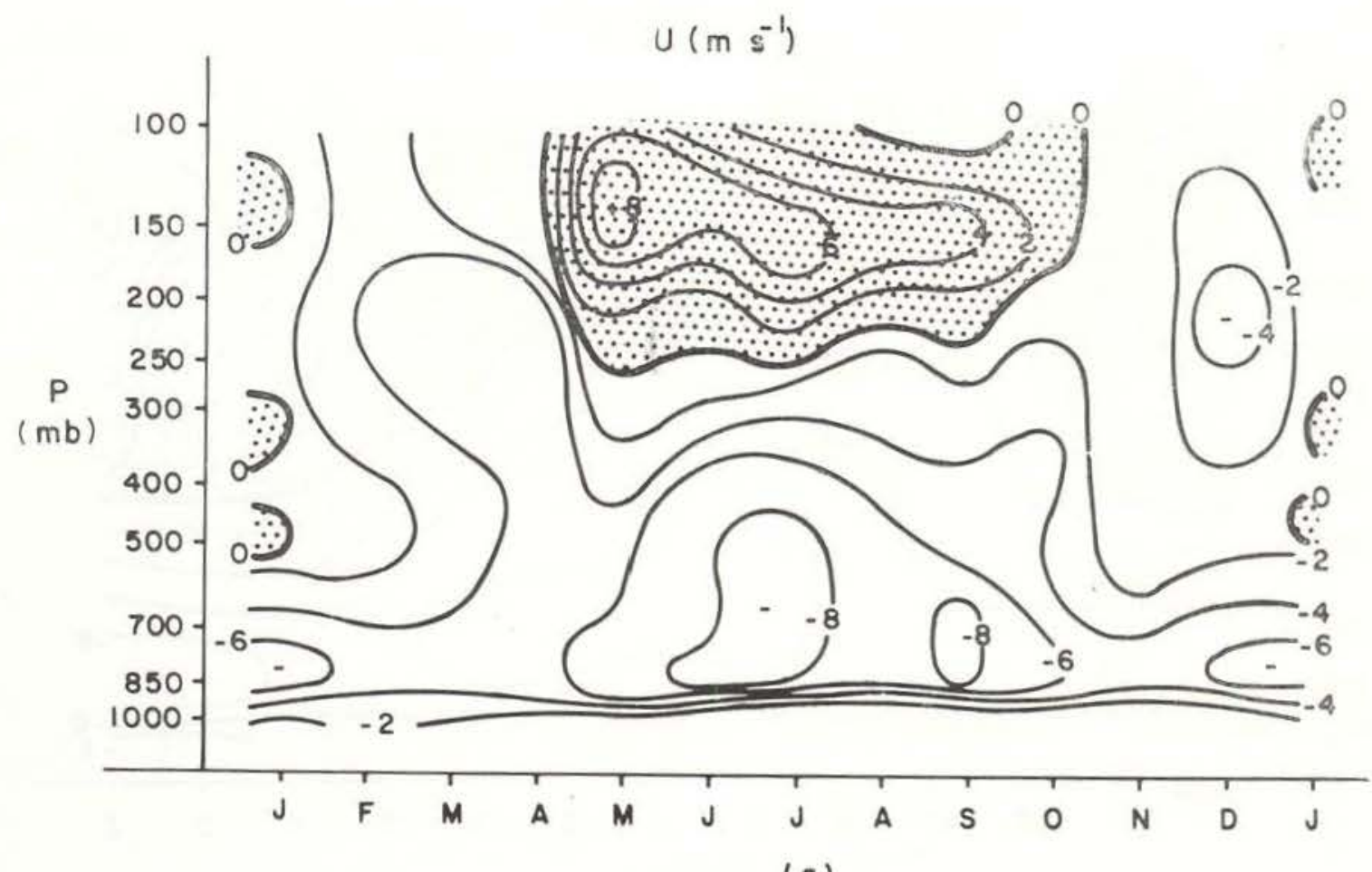

(a)

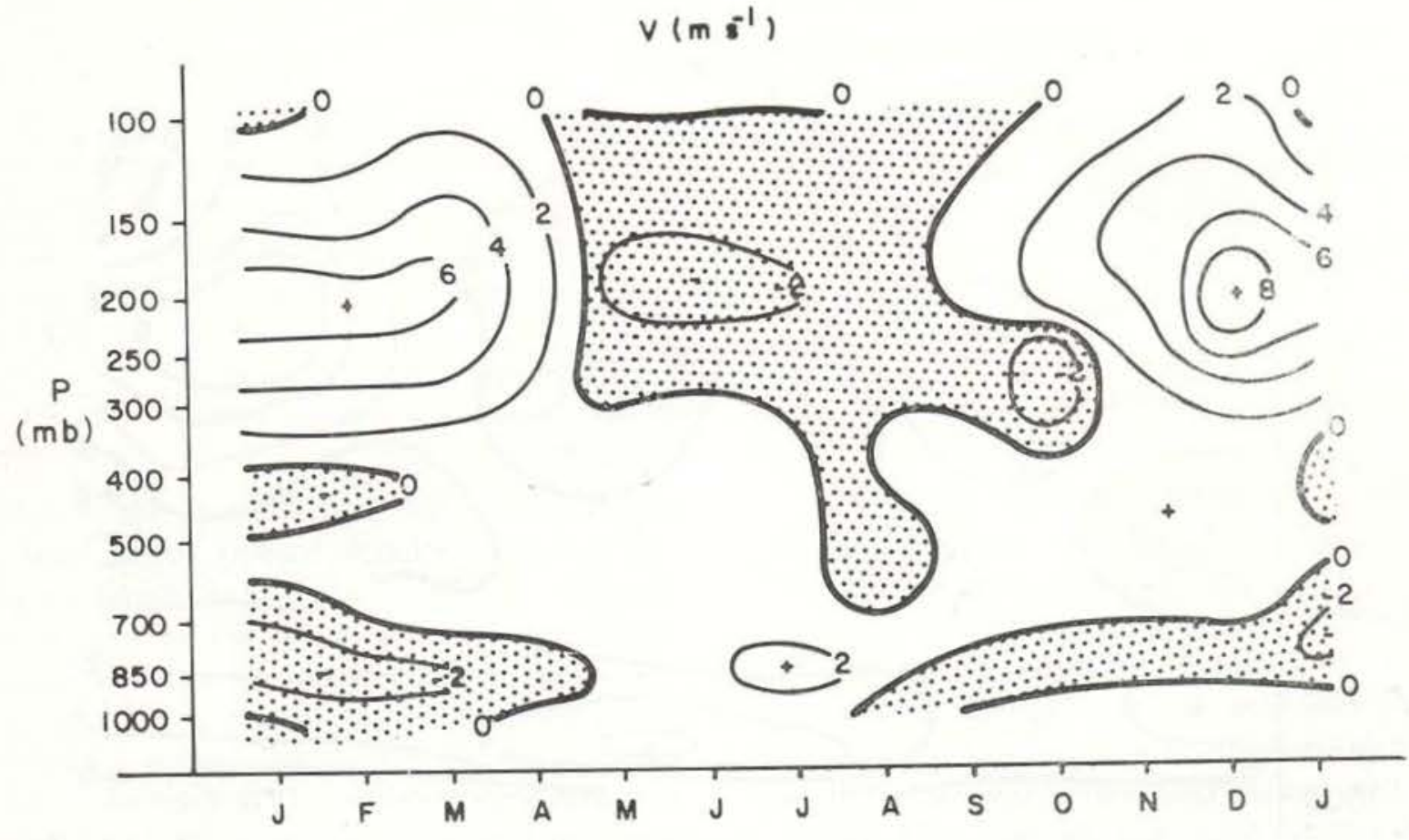

(b)

Fig. 3 - Vertical time cross section for Manaus of the climatological means of the (a) zonal and (b) meridional wind components. Shaded areas correspond to pozitive zonal and negative meridional components. 

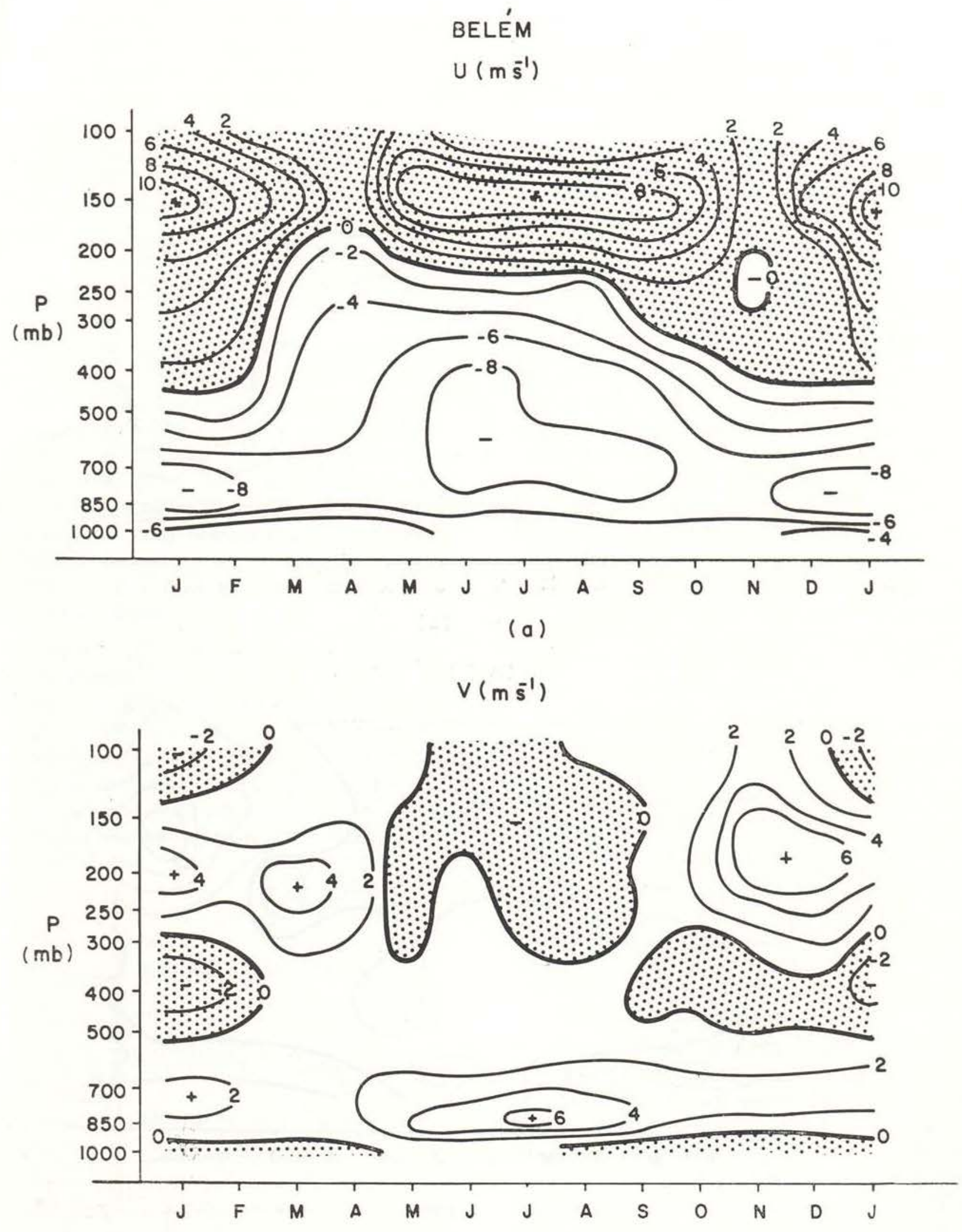

(b)

Fig. 4 - As in Fig. 3, except for Belém. 

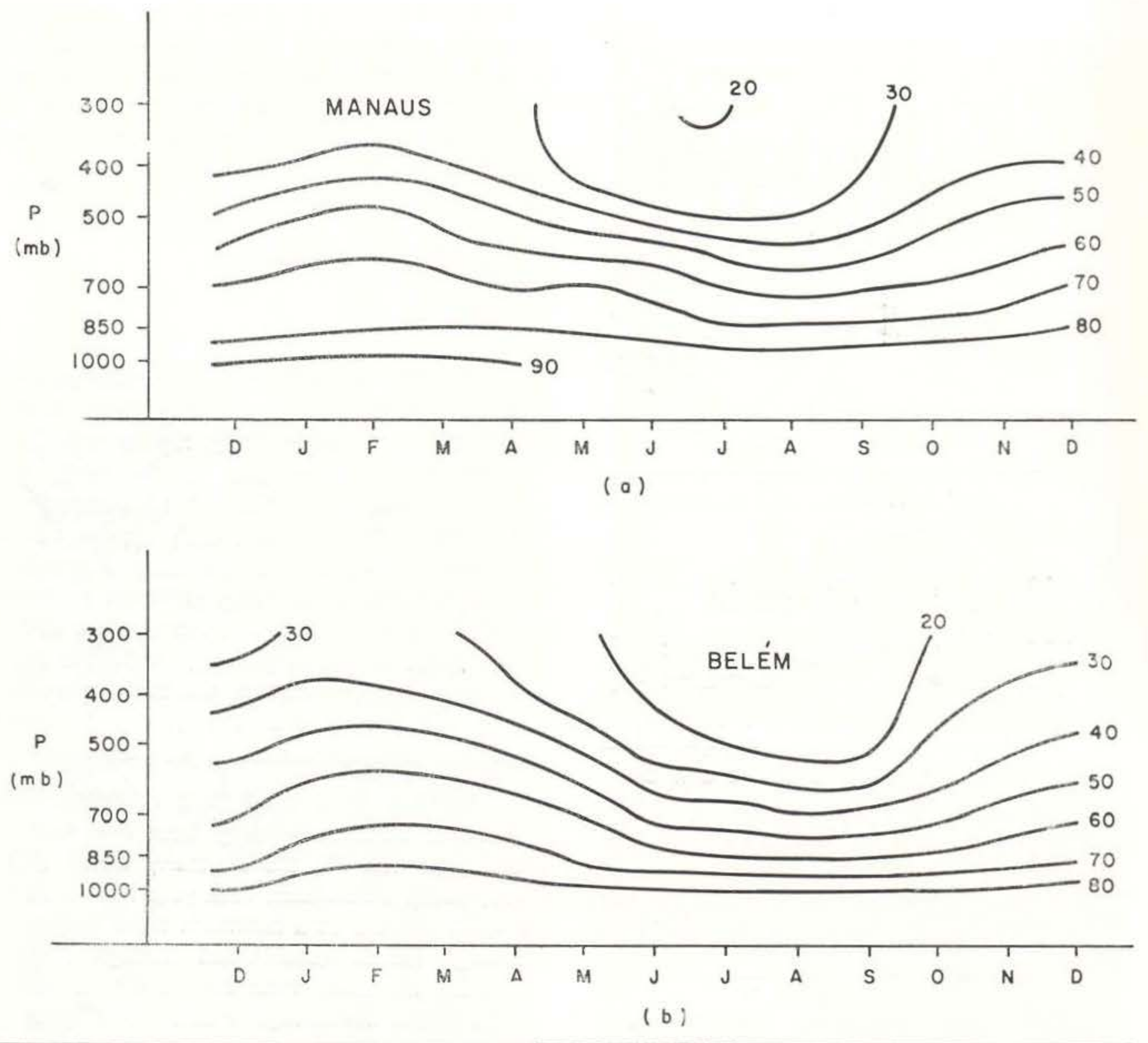

Fig. 5 - Monthly climatological means of relative humidity (in percent) for (a) Manaus and (b) Belém.

system to the south of Manaus. At Belém the low levei winds remain southeasterly but are weaker during the period February through April. Thus, in the average, the intertropical trough zone remains north of Belém during the entire year but is closest from February through April. This agrees with the results of Hastenrath \& Lamb (1977). It seems probable that a trough of low pressure extends from near the mouth of the Amazon, the mean position of the intertropical trough over the Atlantic (Hastenrath \& Lamb, 1977), to Mato Grosso and Bolivia along which convergence and heince convective activity is a maximum.
Between April and May the meridional wind component at low levels at Manaus switches from northerly to southerly indicating that the equatorial trough over the continent is shifting to north of Manaus. This is accompanied at high levels at both stations by a wind shift to the west-northwest. Also both stations show rainfall decreasing during the period May-June as the main convective activity shifts north and northwestward towards height and surface pressure curves at Manaus, Venezuela and Colombia. Both Newell et al. (1972) and Sobral (1979) do not indicate the formation of a $200 \mathrm{mb}$ closed anticyclonic 

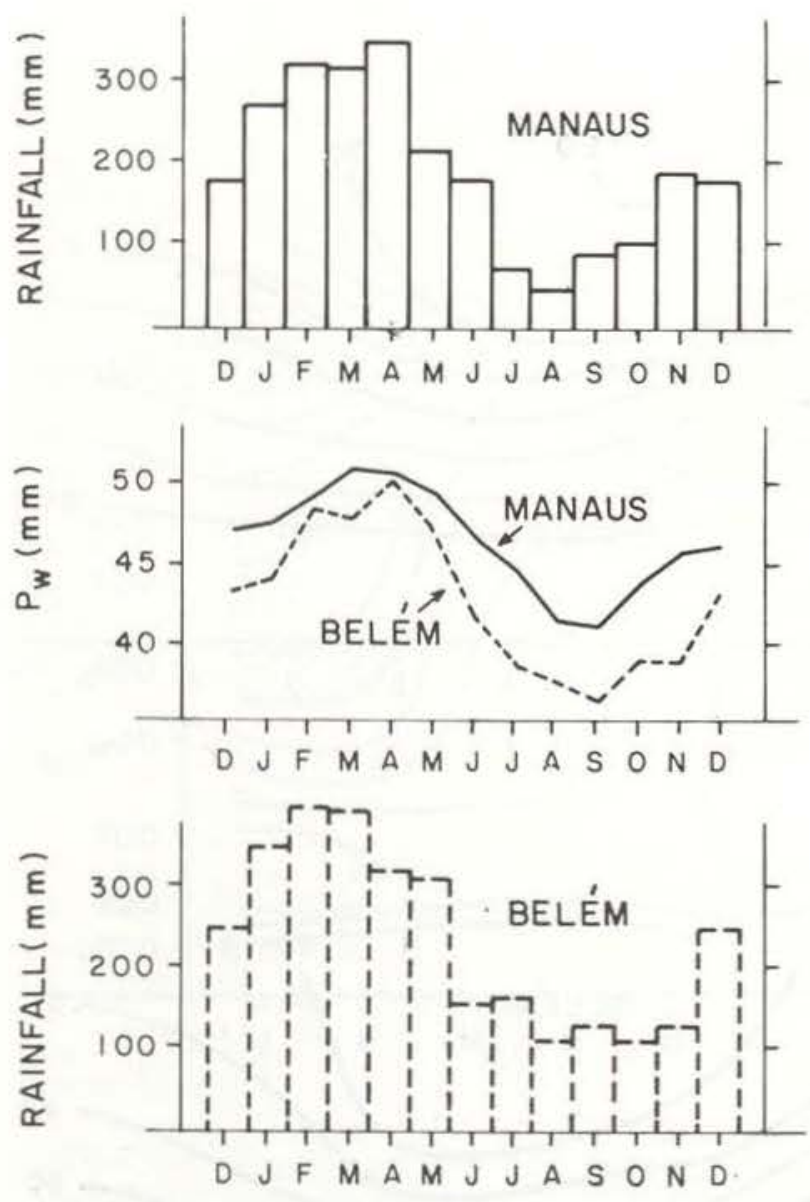

Fig. 6-Monthly climatological means of precipitable water ( $\mathrm{mm}$ ) for Manaus (solid line) and Belém (dashed line) and the corresponding histogram of monthly mean rainfall for each station calculated for the period 19681976.

circulation over Venezuela and Colombia, although both works do show the presence of a ridge. The results at $200 \mathrm{mb}$ for April and October (Sobral, 1979), agree with the discussion above in that the high is located over western Amazonas in October and over central Amazonas in April.

The greater irregularity in the geopotential noted previously (see Fig. 1), may be a result of cold frontal penetrations into the Amazon Basin during the Southern Hemisphere Winter. Such cold frontal penetrations have been shown to have a significant effect on temperature, wind and cloudiness over the Amazon Basin (see e.g. Trewartha, 1961; Brinkman et al., 1971; Parmenter, 1976). It appears plausible that the low level temperature variations be associated with variations in the geopotential height calculated at upper levels. In this respect, intruding cold frontal systems may have la pronounced effect on the intensity of the $200 \mathrm{mb}$ high and convective activity over tropical Brazil.

\section{RESUL.TS (Montl:ly means)}

WIND

Certain characteristics of the monthly mean wind components for Manaus and Belém, Fig. 9 and 10, respectively, repeat with some regularity from one year to the next. The seascnal variation in the $850 \mathrm{mb}$ v-component at Manaus (Fig. 9b) is readily apparent as v, in general, switches from northerly to southerly iduring the period April-May and from southerly in September. The $850 \mathrm{mb}, \mathrm{v}$-component at $\mathrm{Ma}$ naus (Fig. 9a) is, in general, weakest in April and November, which are the times when the equatorial trough over the continent passes Manaus (see discussion in previous section).

The low level wind field at Belém also shows a certain regularity from one year to the next. The $850 \mathrm{mb}$ southerly winds (Fig. 10b) reach a maximum each year from June to August and are at a minimum from December through March (sometimes through April). The $850 \mathrm{mb}$ zonal wind comopnent at Belém (Fig. 10b) is not as regular as the v-component. However, the $1000 \mathrm{mb}$ zonal wind does show certain regularity in that there are minima present from December through April each year.

The upper troposheric zonal winds at both stations (Fig. 9a and 10a) show the presence of westerlies during the Southern Hemisphere winter months, although the intensity and times of occurrence are quite variable. Also, due to the relative position of the $200 \mathrm{mb}$ high with respect to Manaus and Belém, Belém normally does not observe mean easterlies during the Southern Hemisphere Summer, a feature which is observable with regularity at Manaus (see Fig. 8 for an illustration of the above). 

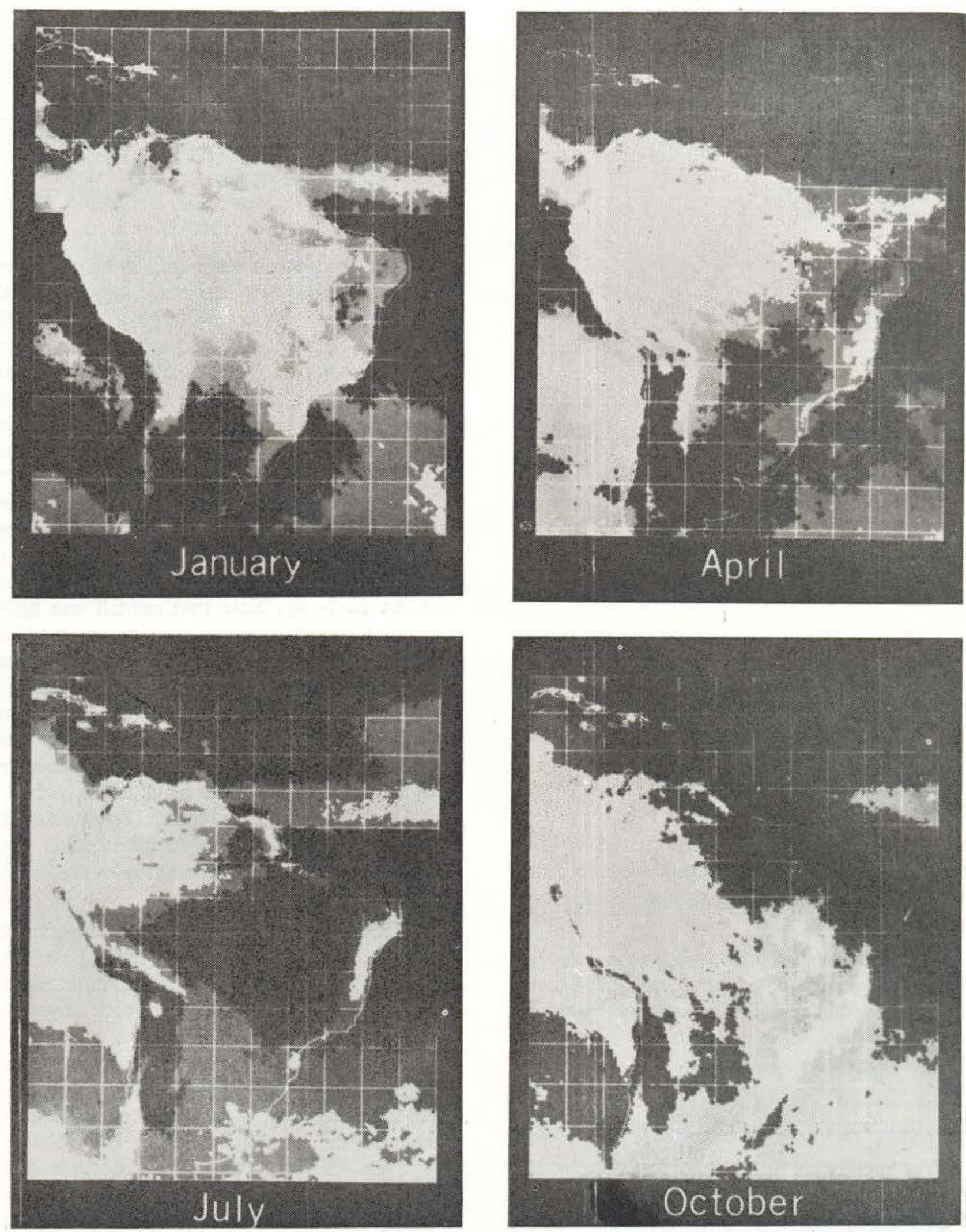

Fig. 7 - Mean brightness charts constructed from visible satellite data. (After Miller and Feddes 1971, pp. 210, 214 , 218 and 222). 


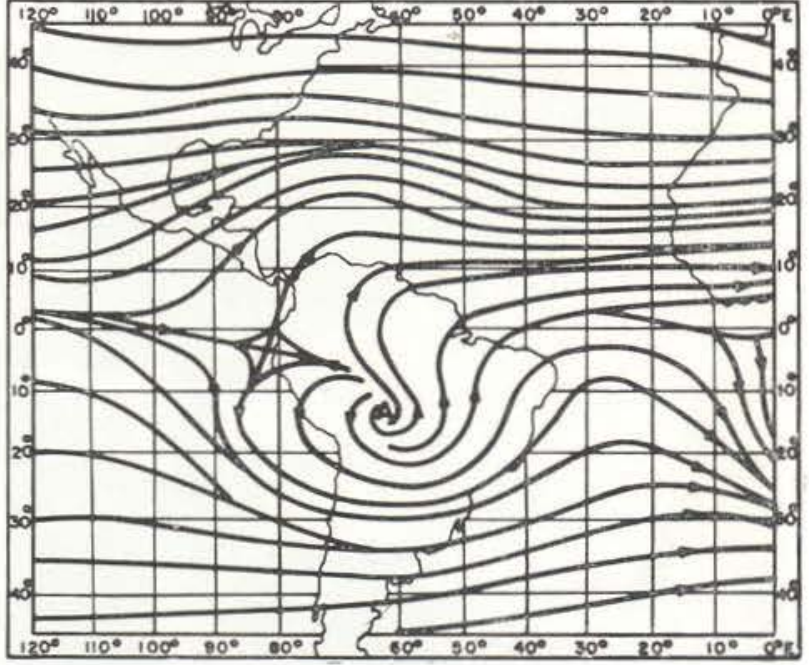

Fig. 8 - Streamlines at $200 \mathrm{mb}$ for December through February. Adapted from Newell et al. (1972), p. 122.

PRECIPITABLE WATER

Monthly rainfall totals and monthly means of precipitable water (Pw) for both stations are shown in Fig. 11. As mentioned above, the months of heaviest rainfall agree fairly well with the months in which $\mathrm{Pw}$ is a maximum. Although the climatological means, presented earlier, show precipitable water to be greater at Manaus than at Belém, it is apparent from Fig. 11 that this is not always the case. During the Southern Hemisphere Summers of 1973 and 1974 Belém, registered higher values of Pw than Manaus.

The upward trend in $\mathrm{Pw}$ noted at both stations is probably due to the use of a different relative humidity sensor beginning about the end of 1972 .

A comparison made between monthly means of precipitable water calculated using the NCC data and Pw calculated using the more complete data set available from IAE showed very little difference.

\section{Discussions (Monthly means)}

As mentioned in the introduction, annual rainfall at stations within the Amazon Basin varies by as much as $\pm 30 \%$ from the long term mean. It was suggested that such variations may be due to large scale circulation changes such as those shown to correlate with rainfai! anomalies in Northeast Brazil. To exemplify how the large scale flow affects rainfall over the Amazon Basin, the horizontai divergence within the triangle formed by $\mathrm{Ma}$ naus, Belém and Vilhena was calculated at each standard pressure level using monthly mean winds. The method for calculating the horizontal divergence is the same as that first proposed by Bellamy (see Haltiner \& Martin, 1957: 315 or Kagano, 1979) .

The horizontal divergences were then used to calculate vertical motions using the continuity equation. The results for 1971 and 1972 are shown in Fig. 12. Also indicated in Fig. 12 are the monthly rainfall totals averaged for three stations within the triangle. Note that the months characterized by sinking motion $(\omega>0)$ are, in general, the driest months. Consider the period October-December 1971. October was characterized by nearly zero mean vertical motion, while November had strongrising motion $(\omega<0)$. December, on the other hand, was characterized by sinking motion $(\omega>0)$. Note that rainfall was heaviest ciuring November and then dropped off markedly in December. The monthly mean relative humidity showed the same variation as the rainfall. Precipitable water (Fig. 11) at both Manaus and Belém shows a reduction from November to December. Thus it appears that large scale convergence or divergence has a pronounced effect on rainfall and moisture content of the air over the Amazon Basin. This result is in general agreement with the results of Marques (1978).

Recently, Kousky (1980) and Marques (1978) showed considerable diurnal variation in rainfall activity at Belém, which he attributed ot the local land-sea breeze circulation systems. During the nighttime considerable convergence and rainfall occurs along the coast (Soure), while Beiém remains dry. If we assume rising motion along the coast due to convergence between the southeast trades and relatively light, or even possibly offshore winds along the coast, then to complete the circulation sinking motion would be expected at points just inland, e.g. near Belém. The sinking motion would have the effect of drying the air, thus giving Belém a relatively low value of Pw. 


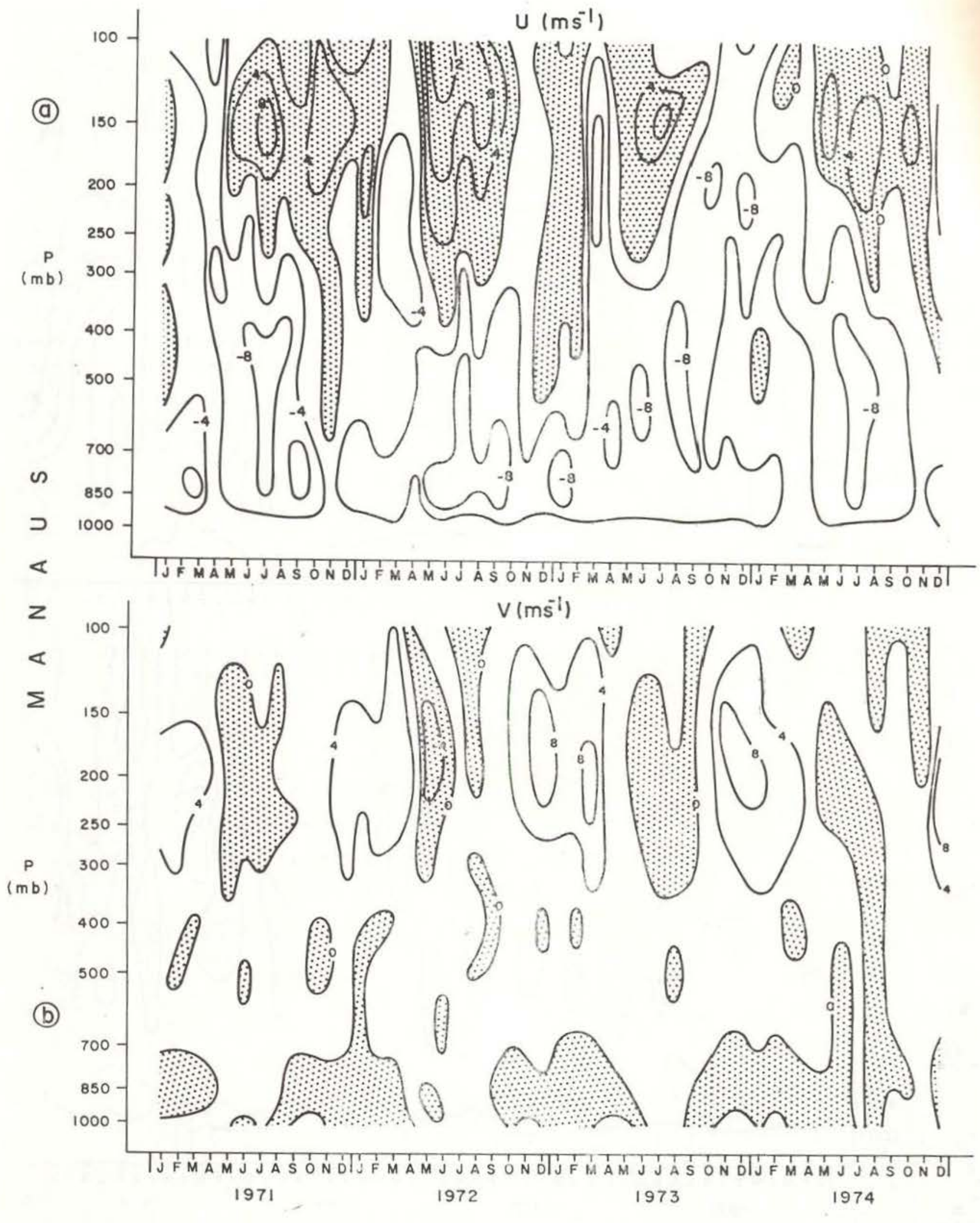

Fig. 9-Vertical time cross sections for Manaus of the monthly mean (a) zonal and (b) meridional wind components. Shaded areas correspond to positive zonal and negative meridional components. 

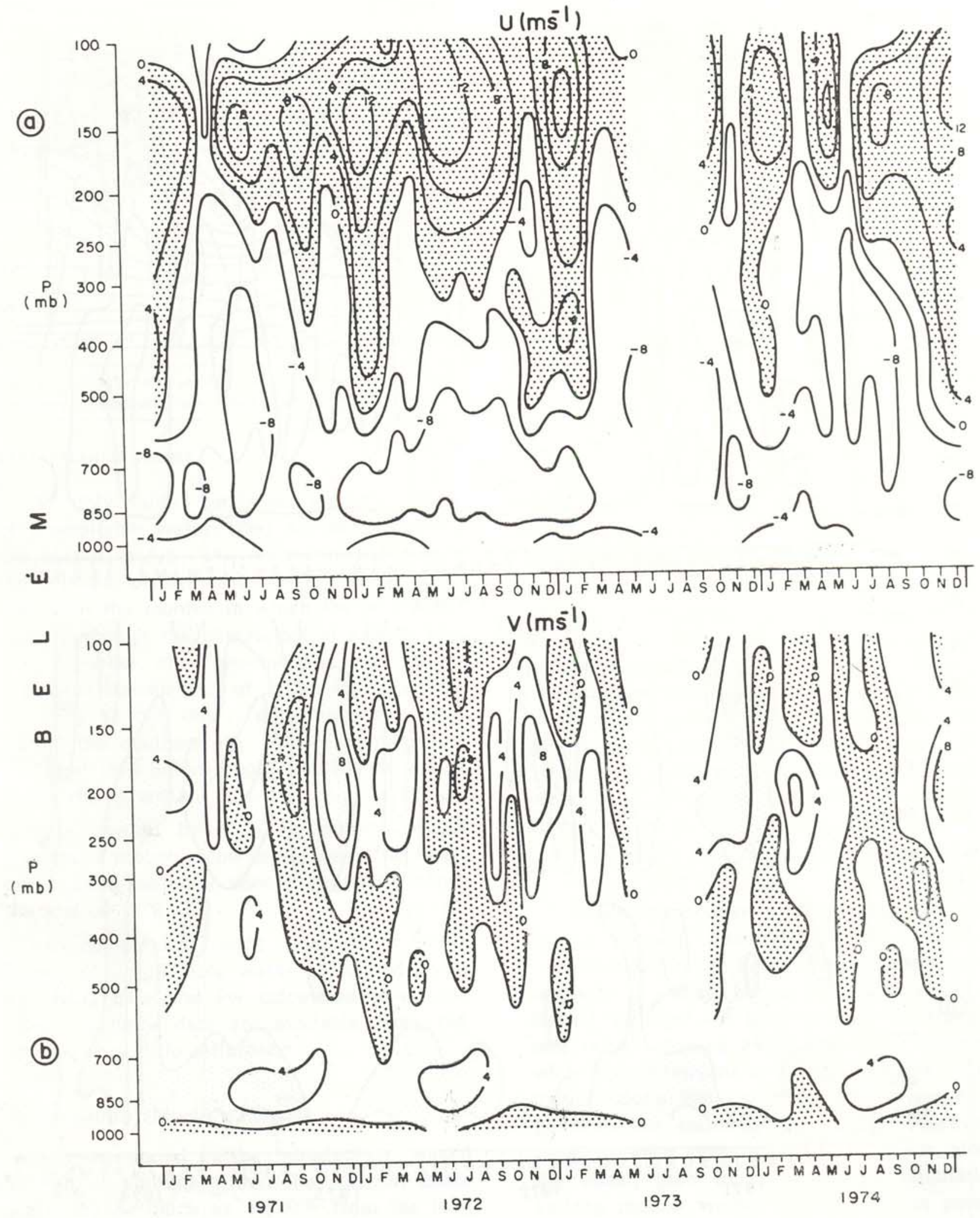

Fig. 10 - As in Fig. 9, except for Belém. 
Once the sea breeze develops and begins to propagate inland, reaching Belém during the late afternoon, rising motion would lead to increasing values of $\mathrm{Pw}$. In fact, increased convective activity at any location would tend to moisten the troposphere thus increasing the vaiue of $\mathrm{Pw}$.

Although most soundings within tropical Brazil are made at 1200 , an effort was made to take 0000 GMT soundings during June-September 1974 in collaboration with the GARP Atlantic Tropical Experiment. The monthly mean values of $\mathrm{PW}$ at both the 0000 GMT and 1200 GMT times for both Manaus and Belém are listed in Table 1. The effect of the sea breeze at Belém is quite obvious with an average of $12 \%$ more precipitable water at 0000 GMT. The results at Manaus do not show this same sort of diurnal variation. In fact, on the average the precipitable water content at, 0000 GMT is slightly less than at 1200 GMT.

A possible explanation for this apparent reversal at Manaus may be inferred from the results of Kousky (1980). Kousky suggested that nocturnal precipitation, occurring about $500 \mathrm{~km}$ inland from the coast, is a result of sea breeze induced convection which continues o propagate inland during the nighttime hours. To support this hypothesis, Kousky presented a sequence of infrared satellite pictures for July 1979 which clearly shows the formation of convection along the coast and its subsequent inland propagation.

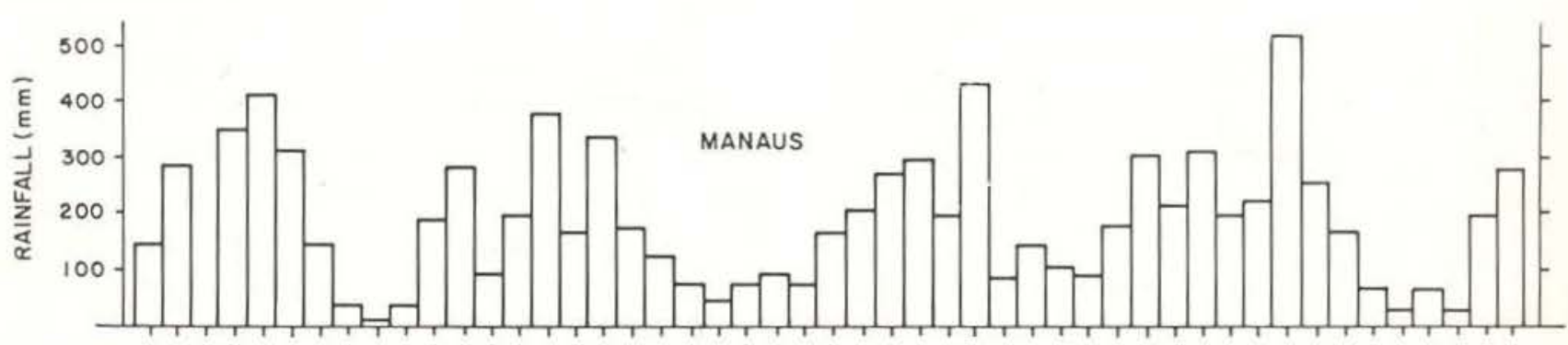

DJFMAMJJASONDJFMAMJJASONDJFMAMJJASONDJFMAMJJASOND 1971 1972 1973 1974

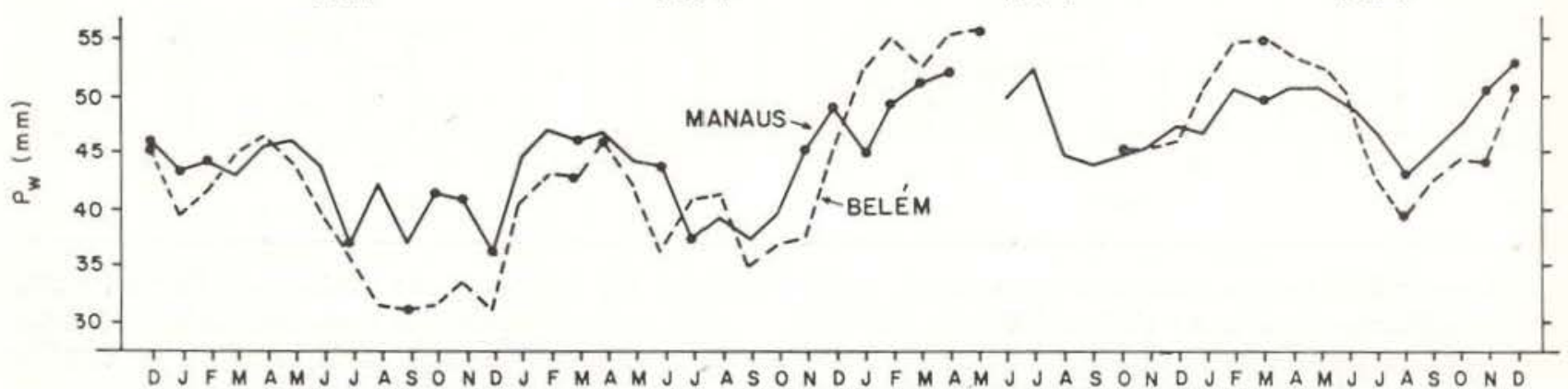

D J F M A M J J A S O NDJFMAMJJASONDJFMAMJJAS O N D J F MAM J J A S O N D

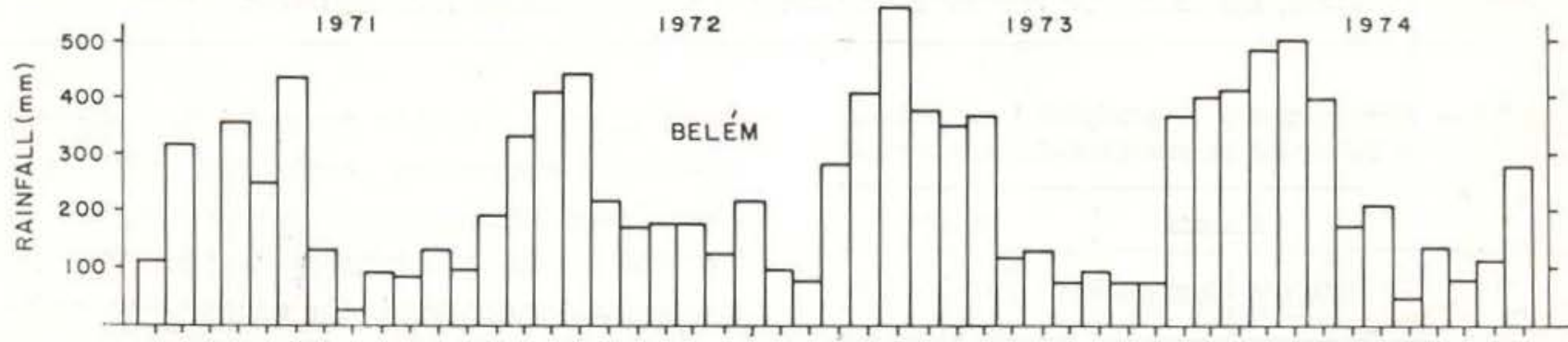

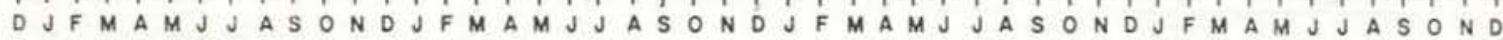
1971 1972 1973 1974

Fig. 11 - Monthly means of precipitable water ( $\mathrm{mm}$ ) and the corresponding monthly rainfall (mm) totals for Manaus and Belém. December 1970-December 1974. The upward trend in PW is probably due to a change in the relative humidity sensor. 

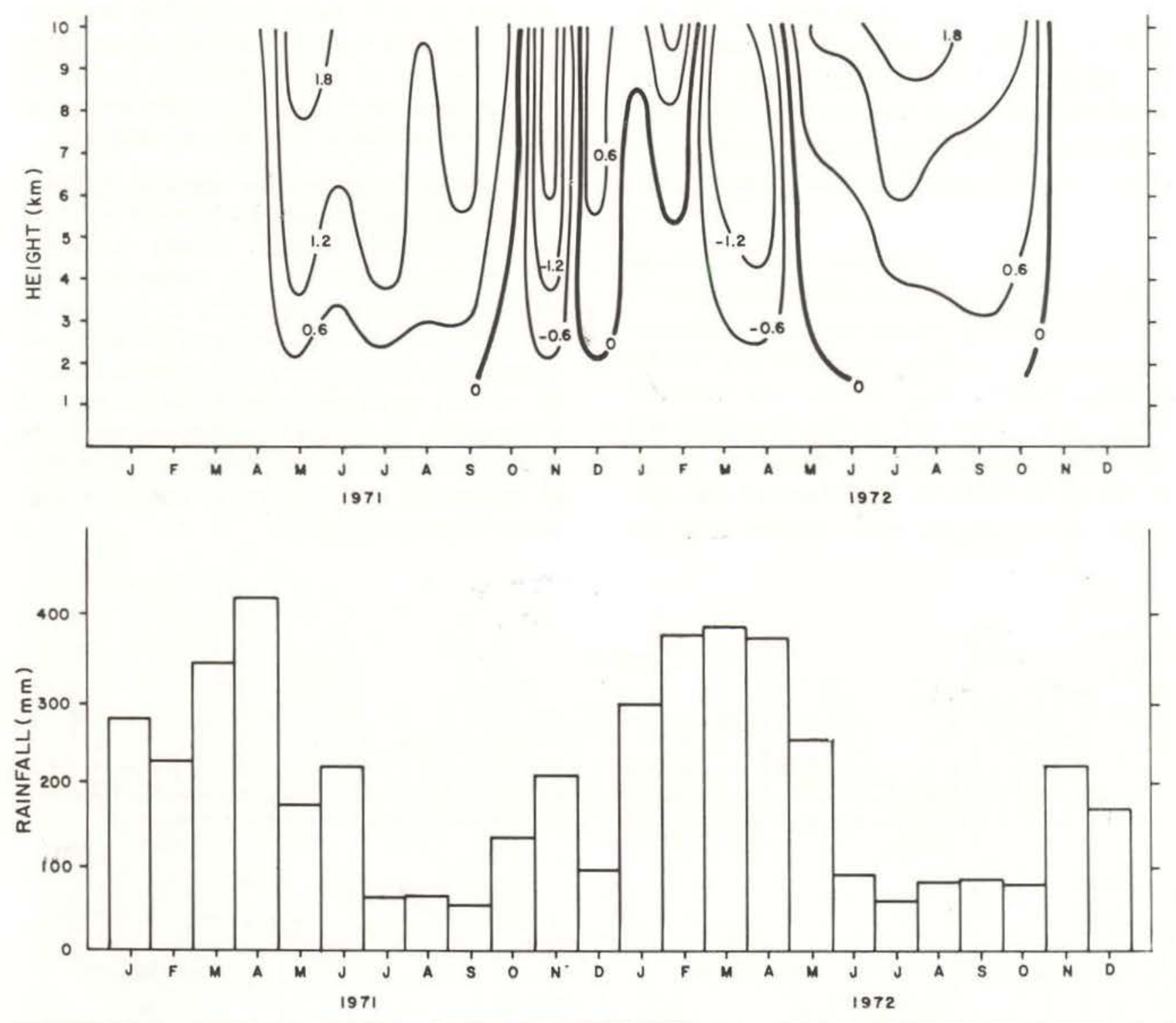

Fig. 12 - Vertical motion (microbars per second), upper figure, for the triangle whose vertices are Belém ( $1^{\circ} 23^{\prime} \mathrm{S}$, $\left.48^{\circ} 29^{\circ} \mathrm{W}\right)$ Manaus $\left(3^{\circ} 8^{\prime} \mathrm{S}, 60^{\circ} 1^{\prime} \mathrm{W}\right)$ and Vilhena $\left(12^{\circ} 44^{\prime} \mathrm{S}, 60^{\circ} 8^{\prime} \mathrm{W}\right)$, and a histogram of mean monthly rainfall within the triangle. Stations used in calculating the mean rainfall are: Alto Tapajós $\left(7^{\circ} 21^{\prime} \mathrm{S}, 57^{\circ} 31^{\prime} \mathrm{W}\right)$. Altamira $\left(3^{\circ} 13^{\prime} \mathrm{S}, 52^{\circ}\right.$ $\left.12^{\prime} \mathrm{W}\right)$ and Itaituba $\left(4^{\circ} 16^{\prime} \mathrm{S}, 55^{\circ} 59^{\prime} \mathrm{W}\right)$. Negative values correspond to resing motion.

TABLE 1 - Monthly means of precipitable water $(\mathrm{cm})$ at Belém and Manaus (June-September 1974)

\begin{tabular}{|c|c|c|c|c|}
\hline \multirow[b]{2}{*}{ Month Hour } & \multicolumn{2}{|c|}{ Manaus } & \multicolumn{2}{|c|}{ Belém } \\
\hline & $1200 \mathrm{GM}$ & $0000 \mathrm{GM}$ & 3000 GMT & 1200 GMT \\
\hline June & 4.95 & 4.76 & 5.03 & 5.24 \\
\hline July & 4.96 & 4.53 & 4.31 & 5.12 \\
\hline August & 4.31 & 4.36 & 3.93 & 4.59 \\
\hline September & 4.56 & 4.65 & 4.26 & 4.71 \\
\hline Mean & 4.63 & 4.57 & 4.38 & 4.92 \\
\hline
\end{tabular}

It seems plausible to conclude that the organized convection associated with the coastal sea breeze is an important mechanism increasing the precipitable water. The increased water content in the column, especially in the lower troposphere $(850-700 \mathrm{mb})$ is then advected inland whether or not it is associated with active convective cells, and arrives in the Manaus area in the early morning (around 1200 GMT). For the moisture to be advected 
$1000 \mathrm{~km}$ in about 18 to 21 hours indicates a speed of $13-15 \mathrm{~m} \mathrm{~s}^{-1}$, which is fairly close to the climatological mean wind speeds during the period June through September (Figs. 3 and 4).

\section{Conclusions}

The seasonal variation in rainfall over Amazonas appears to be related to the position and intensity of a high pressure system located in the upper troposphere $(200 \mathrm{mb})$. The winds and geopotential height at both stations agree well with the argument that the the high makes a complete circuit beginning in January over Bolivia and Mato Grosso, Brazil, moving northward in April to the equator, then northwestward to Venezuela and Colombia by June and July, and finally returning to Bolivia by way of Peru and western Amazonas, Brazil. Interannual variations in the intensity of this high may be linked to mid-latitude influences such as the low latitude penetration of cold frontal systems.

Monthly variations in total precipitation have been shown to be related to the divergence and vertical motions calculated using monthly mean winds over a fairly large area. This suggests that large scale circulation changes are probably the main cause for interannual and monthly rainfall variations.

On the average, the precipitable water is greater at Manaus than at Belém. However, evidence has been presented which shows that this is not always the case and that the diurnal variation of $\mathrm{Pw}$, differences between the monthly means claculated at 1200 GMT and those calculated at 0000 GMT, may be quite large.

\section{ACKNOWLEDGEMENTS}

The authors wish to thank Dr. Antonio Divino Moura for reviewing the manuscript and also for his encouragement and suggestions during the preparation of this paper. We also wish to thank the personnel at the Instituto de Atividades Espaciais, Centro Técnico Ae- roespacial, São José dos Campos, for their support in acquiring radiosonde data for $\mathrm{Ma}$ naus and Belém.

This work is an extension of the second author's M.Sc. dissertation.

It was partially supported by Financiadora Estudos e Projetos (FINEP) through Convênio B 28/79/002/00/00 Modelagem Atmosférica FINEP/CNPq.

\section{Resumo}

São calculadas as médias climatológicas e mensais para os dados de radiossondagem de Manaus e Belém, para o período de 1968 a 1976. Os dados de eltura geopotencial e vento, nos níveis superiores, mostram evidência do deslocamento meridional do sistema de alta pressão associado à área de convecção máxima. Em baixos níveis, os ventos, particularmente em Manaus, mostram um ciclo anual ligado ao deslocamento meridional do cavado equatorial e sua área de convenção máxima (sistema de alta pressão na alta atmosfera). Em média a água precipitável (pw) é maior em Manaus que Belém. Porém, está em evidência que isso nem sempre é o caso e que existe uma considerável variação diurna em $\mathrm{Pw}$ em cada estação. As médias mensais de movimento vertical são calculadas para a área dentro do triângulo Belém, Manaus e Vilhena, como os vértices. Existe uma correlaçăo muito forte entre o movimento vertical e os totais mensais de precipitação dentro do triângulo, indicando que as variações interanuais e mensais na precipitação podem ser atribuidas às mudanças na circulaçăo atmosférica de grande escala.

\section{REFERENCES}

BRINKMANN, W.L.; WEINMAN, J.A. \& RIBEIRO, M.N. Goés

1971 - Air temperatures in Central Amazonia. 1. Acta Amaonica, 1 (2): 51-56.

DEAN, G.A.

1971 - Three-dimensional wind structure over South America and associated rainfall over Brazil. Fla. State Univ., Dep. Meteorol., Rept., 71-4: 122p.

HALTINER, G.J. \& MARTIN, F.L.

1957 - Dynamical and Physical Meteorology. McGraw-Hill. 470p.

HASTENRATH, S. \& HELLER, L.

1977 - Dynamics of climatic hazards in Northeast Brail. Quart. J. Roy Meteor. Soc., 103: 77-92. 
HASTENRATH, S. \& LAMB, P.

1977 - Climatic Atlas of the Tropical Atlantic and Eastern Pacific Oceans. Univ. of Wisconsin Press, 106p.

KAGANO, M.T.

1979 - Um estudo climatológico e sinótico utilizando dados de radiossondagem (1968-1976) de Manaus e Belém. M. Sc. dissertation. São José dos Campos, Inst. de Pesq. Espaciais. 82p.

KOUSKY, V.E.

1979 - Frontal influences on Northeast Brazil. Mon. Wea. Rev., 107: 1140-1153.

1980 - Diurnal rainfall variation in Northeast Brazil. Mon. Wea. Rev., 108: 488-498.

MARQUES, J.

1978 - A transferência horizontal de vapor d'água na troposfera e a hodrologia da bacia amazônica. Ph.D. dissertation. Univ. de São Paulo, Escola Superior de Agricultura "Luiz de Queiróz". 11p.

MARQUES, J.; SANTOS, J.M. dos; VILA NOVA, N.A. \& SALATI, E.

1977 - Precipitable water vapor flux between Belém and Manaus. Acta Amazonica, 7 (3): 355-62.

MILLER, D. \& FEDDES, R.G.

1971 - Global Atlas of relative cloud cover 1967. 1970. Washington, Dept. Comm. NOAA, US Air Force (AWS), 237p.
NAMIAS, J.

1972 - Influence of Northern Hemisphere general circulation on drought in Northetst Brazil. Tellus, 24: $336-342$.

NEWELL, R.E.; KIDSON, J.W.; VINCENT, D.G. \& BOER, G.J.

1972 - The General circulation of the Tropical atmosphere. Massachusetts, Inst. of Tech. 258p.

PARMENTER, F.C.

1976 - A Southern Hemisphere cold front passage at the equator. Bull. Amer. Meteor. Soc. 57: $1435-1440$

SNOW, J.W.

1976 - The climate of northern South America. Climates of Central and South America. v. 12, World Survey of Climatology. W. Schwerdtfeger, Ed., Elsevier. p. 295-403.

SOBRAL, Z.R.

1979 - Um estudo climatológico dos campos de vento e de temperatura nos níveis superiores sobre a América do Sul. M. Sc. dissertation. São José dos Campos, Inst. Pesq. Espaciais. 88p.

TREWARTHA, G.T.

1961 - The Eart's Problem Climates. University of Wisconsin Press. 334p.

(Aceito para publicação em 25/05/81) 